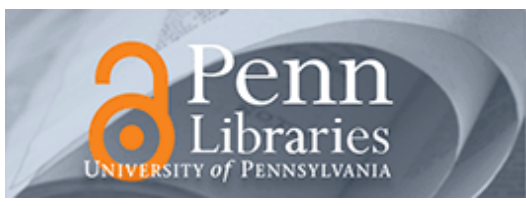

University of Pennsylvania
ScholarlyCommons

Departmental Papers (ASC)

Annenberg School for Communication

1987

\title{
Jerome, Augustine and the Stesichoran Palinode
}

Kathleen Hall Jamieson

University of Pennsylvania, kjamieson@asc.upenn.edu

Follow this and additional works at: https://repository.upenn.edu/asc_papers

Part of the Speech and Rhetorical Studies Commons

\section{Recommended Citation}

Jamieson, K. H. (1987). Jerome, Augustine and the Stesichoran Palinode. Rhetorica, 5 (4), 353-367. Retrieved from https://repository.upenn.edu/asc_papers/736

This paper is posted at ScholarlyCommons. https://repository.upenn.edu/asc_papers/736

For more information, please contact repository@pobox.upenn.edu. 


\section{Jerome, Augustine and the Stesichoran Palinode}

\section{Disciplines}

Communication | Social and Behavioral Sciences | Speech and Rhetorical Studies 


\section{KathleEn JAMieson}

\section{Jerome, Augustine and the Stesichoran Palinode} has tantalized scholars for centuries. ${ }^{1}$ Augustine's correspondence with Jerome, writes Brown, "is a unique document in the Early Church. For it shows two highly-civilized

\footnotetext{
'See, for example: Phillippus de Barberiis, Discordantiae Sanctorum Hieronymi et Augustine (Rome, 1841): Frederic W. Farrar, Lives of the Fathers, Il (New York: Macmillan and Co., 1889), pp. 259-267; Dufey, "Controverse entre saint Jerome et saint Augustine d'apres leurs lettres," Revue du Clerge francais, 25 (1901), pp. 141-149; Georg Grutzmacher, Hieronymus: Eine biographische Studie zur alten Kirchengeschichte, III (Berline, 1908); Ferd. Cavallera, Saint Jerome: Sa Vie et Son Oeuvre, I (Paris: Edouard Champion, 1922), pp. 297-306 and vol. II, pp. 47-56; Le R. P. Largent, Saint Jerome (Paris: Librairie Lecoffre, 1928), pp. 102-117; Father Hugh Pope, O.P., Saint Augustine of Hippo (London: Sands and Co., 1937), pp. 210-227; P. Auvray, "S. Jerome et S. Augustine," Recherches de Science Religieuse, XXIX (1939), Pp. 594-610; G. Simard, "La Querelles de deux Saints," Revue de L'Universite d'Ottawa, XII (1942), pp. 15-38; Jean Steinmann, Saint Jerome (Paris: Editiones du Cerf, 1958), pp. 273-277; Peter Brown, Augustine of Hippo, (Berkeley: Univ. of California Press, 1967), p. 274ff; J. N. D. Kelly, Jerome (New York: Harper and Row, 1975), pp. 270ff.; Henri Marrou, Saint Augustin et l'augustinisme, (Editions du Seuil, nd), p. 67; Robert O'Connell, "When Saintly Fathers Feuded: The Correspondence between Augustine and Jerome," Thought: A Review of Culture and Idea, LIV (Dec 1979), Pp. 244-264; David Wiesen, St. Jerome as a Satirist (Ithaca: Cornell, 1964), p. 235ff; H. H. Lesaar, Saint Augustine (London: Burns Oates and Washbourne Ltd., 1931), pp. 214-220; Rebecca West, Saint Augustine (London: Thomas Nelson and Sons Ltd, 1933), pp. 114-118.
}

(C) The International Society for the History of Rhetoric Rhetorica, Volume V, Number 4 (Autumn 1987) 
men conducting with studied courtesy, a singularly rancorous correspondence." 2 Yet the rhetorical nature of this "bitter-sweet polemic ${ }^{\prime 3}$ has received only a few synoptic pages of scholarly commentary.

The exchange began in 394 when Augustine wrote Jerome (Ep. XXVIII) asking for clarification of a position Jerome had advanced in his commentary on the Epistle to the Galatians. In all, their correspondence would include eighteen letters, nine penned by each.

Augustine's query centered on Jerome's interpretation of Galatians $2: 11-14$. This page was the source of much controversy in the early Church for it raised important questions about the accuracy of the writers of the epistles, in this case Paul. Augustine's question reduces to this, How is it possible to defend the authority of Scripture, if, as Jerome contends, Paul lies about Peter's treatment of the Jewish community? In place of Jerome's contention that Paul lied, Augustine argues that Peter wrongfully had adapted to the customs of the Jewish community and that Paul had reported Peter's behavior truthfully.

This first letter of Augustine's failed to reach Jerome. So, in 397, Augustine raised the same issue in a second letter (Ep. XL). But unlike the first, in this letter, Augustine asked that Jerome recant his position by singing a Stesichoran palinode. As you will recall, the poet Stesichorus regained his sight after recanting his attacks on Helen and replacing them with praise. Before the end of the controversy, Augustine could regret clothing his request that Jerome recant in a Stesichoran analogy.

In the offending second letter (Ep. XL) Augustine "beseeched" Jerome to:

Chant what the Greeks call a palinode. . . I don't ask this so that you may recover the faculty of spiritual sight - far be it from me to say that you have lost it! - but that, having eyes both clear and penetrating, you may turn them towards that from which, in unaccountable dissimulation (dissimulatio), you have turned them away, refusing to see the disastrous consequences which would follow on our once admit-

${ }^{2}$ Brown, p. 274.

${ }^{3}$ Auvray, p. 594; see also Cavallera, I, 299. Marrou too notes (p. 66) that "il est bien vrai qu'il l'avait un peu facilement pris de haut avec son aine de sept ans." 
ting that a writer of the divine books in any part of his work honorably and piously speaks a falsehood. ${ }^{4}$

When its bearer changed his plans, this letter too was waylaid. As a result, for five years the letter urging Jerome to recant circulated among Jerome's acquaintances in Rome before a copy finally reached him in 402 .

Commentators agree that Augustine, then a forty-year-old presbyter, inadvertently triggered the wrath of the "irascible hermit $^{\prime \prime}$ Jerome with these two letters. But scholars do not agree on what in particular about Augustine's letters summoned Jerome's rancorous response. Nor do they recognize the artful rhetorical strategy the former teacher of rhetoric employed in subsequently wooing Jerome.

Some contend that Augustine's mistake was "sending Jerome a letter questioning certain aspects of Jerome's scholarship" ${ }^{\prime 6}$ notably Augustine's claim that "Jerome's project of translating the Hebrew Scripture from the original into Latin was superfluous labor." Others chide Augustine for "taking a 'haughty attitude' toward Jerome." 7 Similarly, West concludes that "Augustine's approach to him would be considered pert and familiar even in a close friend and equal." 8 Still others blame the controversy on "a series of accidents": ${ }^{9}$ the friend to whom Augustine's first letter was entrusted failed to notify Jerome of its existence or Augustine that it had failed to reach Jerome. To compound the tension, the messenger circulated copies of the undelivered letter prompting rumors that Augustine had sent to Rome a libellus against Jerome. Some do acknowledge that Jerome was angered by Augustine's request for a palinode. ${ }^{10}$ But even these fail to recognize that it was specifically that request that triggered Jerome's rancorous response.

${ }^{4}$ J. P. Migne, Ep. XL. (Cap IV. 7.) in Pat. Latina, vol. 33 (Parisus, 1841) hereafter cited as PL. The most famous Stesichoran palinode in the history of rhetoric probably is the one uttered by Socrates in Phaedrus. 243.

${ }^{5}$ The characterization is Francis X Murphy's. See A Monument to Saint Jerome. ed. Francis X Murphy (New York: Sheed and Ward, 1952), pp. 3-12.

${ }^{6}$ Wiesen, pp. 235-6.

${ }^{7}$ Steinmann, p. 277.

${ }^{8}$ West, p. 116.

${ }^{9}$ Farrar, p. 259.

${ }^{10} \mathrm{cf}$. Farrar, p. 261. 
The tenacity with which Jerome returns to the requested palinode betrays his indignation at the request. Indeed, Jerome's response (Ep. CII) to Augustine's second letter opens by focusing not on that letter's content but on the palinode: "In this supposed letter Uerome has only a copy] I am exhorted to sing a palinode recanting a mistaken interpretation of the apostle's writing and to imitate Stesichorus who, fluctuating between vituperation and praise of Helen, by praising her recovered the eyesight he had forfeited by speaking ill of her." 11

Then, Jerome, who is ten years Augustine's senior, launches an implied attack on Augustine, who since the original letters were dispatched, had, on the death of Valerius in 396 become Bishop of Hippo. "But it is well known to a person of your wisdom that everyone is smug about his own opinion and that it is childish as adolescents are prone to do to seek to capture fame for oneself by attacking famous men."

To this point, Jerome coyly has not referred directly to Augustine. However the three personalized adversarial metaphors with which Jerome attempts to drive Augustine into silence make it clear that the earlier comments about childish self-sufficiency were aimed at the Bishop.

The first metaphor in which Jerome casts his relationship with Augustine is an athletic one: "Do not because you are young provoke a veteran in the field of scripture. We have had our time and have run the courses to the best of our strength. It is only just that we should now rest, while you in your time, run great distances."

In the event that Augustine is still contemplating pursuit of the challenge, Jerome sets in place two reinforcing metaphors which argue Jerome's strength and prophesy the destruction of one who would provoke it. The first of the two menacing metaphors is prefaced by a veiled allusion to the rankling palinode: "Lest it appear that quoting the poets is something you alone can do, I remind you of Dares and Entellus."

As the former rhetoric teacher undoubtedly recalled, Entellus is the boxer in Book V of the Aeneid (394-6), whose "blood is chilled and slowed by sluggish age" but who, nevertheless, defeats the brash young Dares. At the close of the fight: "his comrades led

${ }^{11} \mathrm{PL}, 22$ (Ep. CII. $\left.632.1 \mathrm{ff}\right)$ 
Dares to the ships, his failing knees dragging, his head swaying from side to side while from his mouth he spit out clots of flesh and teeth mixed with blood." (467-470)

In the same sentence as the allusion to Entellus is the proverb, "the tired ox walks with a firmer step." Having raised two clear threats and one projection of his own victory, Jerome closes ironically with the assurance, "See how truly I love you in so much as I am unwilling even under challenge to respond and am unwilling to believe that you are the author of that which from any other I would severely rebuke." The nature of the rebuke and its effect have been prophesied in the two threatening metaphors. Both argue that further challenge entails personal risk for Augustine.

The causal link between the requested palinode and Jerome's ire is as clear in a subsequent letter (Ep. CV) to Augustine in which Jerome again allies the requested palinode and a combative metaphor: "But if challenging me as if to single combat you take exception to my views and expect a rationale for what I have written and insist upon what you conclude to be an error and call upon me to recant in a palinode and speak of curing me of blindness, in this I argue that friendship is wounded and the rules of fraternal union broken." 12

Although Augustine has not reiterated his request for a palinode, so deep is the wound inflicted by that request that Jerome has become obsessed with it. It has become the lens through which he perceives their correspondence.

Nowhere in the second letter has Augustine accused Jerome of spiritual blindness. Instead, the letter explicitly discounts that interpretation. After Jerome has raised the issue of the palinode a second time, Augustine (Ep. LXXXII) both apologizes for the unfortunate request and reminds Jerome of the restrictive interpretation his letter originally placed on it:

As for that fact from the life of some bard which I ineptly quoted from the classics, I beseech you not to carry its meaning further than I intended. You will recall that I immediately added: I do not say this so that you may regain spiritual sight-far be it from me to say that you have lost it, but that having clear and certain eyes, you may focus on this matter. I referred to the palinode, [only to say that] . . if we have

${ }^{12}$ PL (Ep. CV. 640.4) 
written something requiring correction, we should imitate Stesichorus, not on account of his blindness, which I neither ascribed to your heart nor feared would overcome you.

Despite that clear explanation, years later, in the letter that sealed the peace between them (Ep. CXII), Jerome returned to his refrain about the offending palinode. And here, as before, he either ignored or dismissed Augustine's unequivocal disclaimers: ${ }^{14}$ "Insofar as I have transgressed, blame yourself who forced me to respond and who made me out to be as blind as Stesichorus." Jerome's insistence on misinterpreting Augustine's call for a palinode raises the question, What in that call so rankled Jerome?

I would suggest that Jerome's self-protective instincts were raised against Augustine when Augustine inadvertently employed a capsulizing phrase dripping with residual meaning from Jerome's painful fight with Rufinus. Before defending that claim, let me briefly explain why the conflict between Rufinus and Jerome so lacerated its apparent victor-Jerome. Jerome and Rufinus had studied together in Rome and spent time in the same monastic community in Aquileia. In their youth, Jerome had written of Rufinus ${ }^{15}$ : "If only our Lord Jesus Christ could grant me quick passage . . . how firmly I could embrace you . . . I beg you not to let me pass completely from sight and mind." The depth of Jerome's affection is revealed in a letter penned in 374: "Do not ask me to estimate his virtues. In him are conspicuously expressed the signs of sanctity." 16

Both Jerome and Rufinus had been disciples of Origen. The works of both are indebted to him. Before some of these works were held to be heretical, Jerome had translated fourteen of Origen's homilies on Jeremiah, fourteen on Ezekiel, nine on Isaiah, thirtynine on Luke and fourteen on the Song of Solomon as well as Liber de Nominibus Hebraicis. Jerome's own commentary on Ephesians was heavily influenced by Origen's.

Rufinus translated Origen's De Principiis, many of Origen's sermons and parts of Commentarius in Epistulas ad Romanos and Com-

\footnotetext{
${ }^{13}$ PL (Ep. LXXXII, IV. 33.)

${ }^{14} \mathrm{PL}$ (Ep. CXII. 751. 18.)

${ }^{15}$ Sancti Evsebii Hieronymi, "Epistvlae III. LIV.," in Corpus Corpvs Scriptorvm Ecclesiasticorom Latinorom (Vindobonae: F. Tempsky, MDCCCCX). Hereafter cited as CSEL.

${ }^{16}$ Ibid. IV. 2.
} 
mentarius in Canticum. Mistakenly attributing it to Origen, Rufinus translated the dialogue De recta in Deum Fide. He also translated the first book of Pamphilus' defense of Origen.

When some of Origen's writings were found to be heretical, both Rufinus and Jerome were vulnerable to accusations that they had perpetuated false doctrine. Jerome moved quickly to disassociate himself from Origen's suspect work. When Rufinus suppressed potentially heretical segments in his translation of De Principiis and, without consulting Jerome, placed that translation under his patronage, Jerome responded by retranslating the work in unexpurgated form and, in a letter which subsequently circulated widely, accused Rufinus of heresy. In fairness to Rufinus, one should note his belief that Origen's works had been corrupted by heretics. In De Adulteratione Librorum Origenis (397), he argued that his translations were acts of restoration not suppression.

In the controversy over Origen's works, Rufinus allied himself with Origen's defender, John of Jerusalem; Jerome embraced the anti-Origenist arguments of Epiphanius of Salamis. After a brief break over the Origenist controversy, in 392 Jerome and Rufinus reconciled. Rufinus' subsequent retranslation of De Principiis rekindled the feud.

Jerome's charge that Rufinus was a heretic was met with Rufinus' Apologia contra Hieronymum. Jerome countered with his venomous Apologia Adversus Libros Rufini probably written in 401. In the first book, Jerome defends his own translation of De Principiis. The second book attacks Rufinus' Apologia ad Anastasium. The Apologia ad Anastasium had been written to the pope in 400 to quiet calls from Jerome's friends for a synod. In this work, Rufinus both declared his faith and claimed that as Origen's translator he should not be held accountable for the content of Origen's writings.

After the publication of these two books, Rufinus sent Jerome a final letter, now lost. Portions of that letter survive in Jerome's Liber Tertius seu Ultima Responsio Adversus Scripta Rufini, Jerome's final reiteration of his attacks on Rufinus. That final document probably was written in either late 401 or early 402 . The date is an important one for it is in 402 that Augustine's letter requesting a palinode finally reached Jerome.

Reading the apologiae of Rufinus and Jerome leaves one with the sense of having helplessly witnessed the bludgeoning of a child. Rufinus was a "philosopher, a kind, affable man with a steady mind ... He lacked intellectual acuity and was a poor 
writer . . Jerome, by contrast, appears obstinate, violent, hypersensitive, absolutistic and domineering, but with a sharp mind." 17

In the Apologia ${ }^{18}$ Rufinus expressed his bewilderment at Jerome's attack: "It is simply not true as he [Jerome] says that he turns the right cheek to one who strikes him on the other. He has unexpectedly turned and bitten one who was stroking and caressing him on the cheek." By contrast, Jerome repeatedly refers to Rufinus as a "snake" ${ }^{19}$ and suggests that his writings stink like rotting corpses. ${ }^{20}$ Jerome ridicules Rufinus' intellect, his translations, his rhetoric and his demeanor: "21 "At home he was like Nero, away from home, like Cato, as contradictory as a Chimera." Indeed, when Jerome learned of Rufinus' death he rejoiced: "Now that the Scorpion has been interred in Sicily .. and the multi-headed hydra has ceased to hiss at us, my time can be devoted to things other than answering the iniquities of heretics ... I shall address (the book of) the prophet Ezechiel." 22

Long after his opponent had withdrawn from the debate, Jerome continued to savage his reputation. His hatred for Rufinus intruded even on the text of his Scriptural commentaries. In the beginning of the sixth book of his commentary on Ezechial, Jerome noted that he had mistakenly believed that "once the Scylla was dead, the Scylla's dogs who bark endlessly would no longer contest against me." 23

${ }^{17}$ Steinmann, p. 293.

${ }^{18}$ PL 21 (309.3)

${ }^{19} \mathrm{cf}$. Comm in Naum. III. 564; Comm in Abacuc. II. 631. Describing heresy and the other evils that affect the Church in serpentine imagery is commonplace in patristic rhetoric and particularly central in Jerome's. Incarnating the devil as a snake dates at least to Genesis. As Jerome recalls (Ep. 124.2), in Luke 10:19 Jesus gave the apostles the power "calcandi supra serpentes et scorpiones." See also Ep. 130: 16.2, 2.5.

${ }^{20}$ Cont. Ruf. ii. 42 . in PL, 23 (510). Specifically, Jerome claims that the dung pile of Rufinus' breast gives off the smell of roses and the stench of rotting corpses. He justifies his conclusion that Rufinus' writings stink by accusing him of acting like a whore (PL 23. 490). The resemblances between the metaphoric lexicon of Jerome and of Martin Luther are striking. For an analysis of the rhetorical figures found in Jerome's letters see John Nicholas Hritzu, The Style of the letters of St. Jerome, (Washington D.C.: the Catholic University of America Press, 1939).

${ }^{21}$ PL 22 (Ep. 125. 945)

"S. Hieronymi Presbyteri, "Prologus," Commentariorum in Hiezechielem in Corpus Christianorum Series Latina (MCMLXIV), LXXV. 11. 18-25. Hereafter cited as CCSL. TLXXV. Prologus.

${ }^{23}$ (VI. 197-8) 
By characterizing Rufinus as a snake and a scorpion, Jerome unmasks the real impact of Rufinus' attacks. In his attack on Vigilianus, Jerome had compared the process by which a scorpion inflicts its wound and the process by which heresy forces venom into the body of the Church. ${ }^{24}$ Just as Rufinus had poisoned the body of the church by infecting her with heresy, so too Rufinus has poisoned Jerome. By implication, then, Jerome's apologia is his way of draining from the body of the Church and from his own body the poison of Rufinus. Jerome persists in attacking a dead scorpion because he must purge the remaining venom from his system.

Jerome's friendship for Rufinus had been transformed into "hatred, pitiable and tragic," ${ }^{25}$ and had transformed Jerome into a bitter, suspicious man. In the conclusion of his apologia Jerome professes that it is simpler to protect oneself from a proclaimed enemy than from an enemy cloaked as a friend. It is in that context, the context created by Jerome's bloody battle with Rufinus, that Jerome's response to Augustine becomes explainable.

Jerome prided himself on both his eloquence and his linguistic facility (the trilingual man, he called himself). The apologia against Rufinus is a carefully crafted document. Additionally, Jerome took pride in his own power of recall. In one letter to Augustine, Jerome takes the role of Moeris and recites three and a half lines of five-line section from Virgil's Ninth Ecologue confident that Augustine will fill in the indicting fourth line. "Time robs us of all, even of memory; often as a boy I recall that with song I would lay the long summer days to rest. Now I have forgotten all my songs. Even voice itself now fails Moeris."

Augustine is expected to add: "wolves have seen Moeris first." By so doing, he indicts himself for his wolf-like behavior toward the aging Jerome. The fragment from Virgil demonstrates Jerome's memory at the same time as it claims that he has been robbed of it.

I have no doubt then that Jerome had stored in memory the lines of argument he used against Rufinus, specifically the demand that Rufinus issue a Stesichoran palinode. In his apologia, Jerome had declared: "if the case is documented, and the witness of many results in condemnation of your impudence, you must sing your palinode in the manner of Stesichorus . . . Nor need you be ashamed of

\footnotetext{
${ }^{24} \mathrm{PL} 23$ (395)

${ }^{25}$ Steinmann, p. 293.
} 
a change of view. Your prestige and notoriety are not so great that you need to feel ashamed at having erred." ${ }^{26}$ Here lies the explanation for Jerome's hypnotic fixation on a single line in Augustine's second letter and also the explanation for Jerome's insistent misreading of that line. In Augustine's request for a palinode, Jerome reads the tone and intent of his earlier use of the phrase against Rufinus. Augustine unwittingly had scraped off what little scar tissue had formed on an old, deep wound and, at the same time, had evoked Jerome's fear that a piece of painful personal history was about to repeat itself.

What then did Augustine's request mean to Jerome? Jerome's request of Rufinus is that of an intellectual superior who gratuitously advises an aspirant that a recantation could not possibly diminish his inconsequential reputation. Jerome assumed from the call for a palinode that Augustine thought himself intellectually superior and considered Jerome's reputation negligible. If Jerome heard Augustine's request in this fashion, his fixation on the phrase, his misreading of it, and his metaphoric threat to beat Augustine toothless are explainable.

Conventional interpretations hold instead that Jerome's response is the inevitable consequence of the suggestion that the monk recant. These interpretations are predicated on the presumption that Jerome could not see or would not admit his own error. In this view, the call to recant is simply a catalyst provoking the arrogant, bilious Jerome to attack. What gives lie to this interpretation is the fact that Jerome does ultimately admit to the point of view Augustine advocates. In his Dialogue cum Pelagianis, Jerome notes that in the eyes of St. Paul even St. Peter was flawed, an acknowledgement that leads him to conclude that one should not complain of one's own inadequacies when one finds that not even the prince of the apostles was blameless. ${ }^{27}$

I do not mean to claim that the call to recant would not have provoked some hostility in Jerome regardless of its antecedent use against Rufinus but rather to suggest that Jerome's prior use of that provocative phrase magnified the insult and for Jerome opened the possibility that Augustine too was an enemy cloaked as a friend.

If the call for a Stesichoran palinode was so provocative why was Jerome's response to Augustine comparatively more restrained

${ }^{26}$ Adv. Ruf. 466.

${ }^{27}$ PL 23 (516) For Augustine's reaction see Ep. 180.5. 
than his response to Rufinus? Jerome's metaphors provide one compelling answer: he perceives himself to be an old man who will be drawn into yet another battle reluctantly, if at all. In addition the battle between Jerome and Rufinus involved the insinuation that Jerome's writing has been adulterated with the Originian heresy. No such charge has been raised here. Moreover, Jerome, a presbyter, is hesitant to become embroiled in conflict with the eloquent Bishop Augustine. The risk in tangling with Rufinus was far less. So there is good ground for the hesitancy implied by Jerome's metaphors.

Yet, in case Augustine doubts the vehemence with which Jerome can respond and, perhaps, to warn Augustine that Jerome sees him as a potential Rufinus, Jerome dispatches with his first long letter of response a copy of his interchange with Rufinus. I would argue then that when Augustine compared Jerome's assault on Rufinus with the letter of the threatening metaphors he saw incubating in the latter the fully fleshed attacks of the former.

Augustine generally is blamed for precipitating Jerome's rancorous reaction but credited with skillfully extricating himself from the wrath it prophesied. Had Augustine written nothing but that letter, reasons Sailer, he would still deserve to be considered the finest soul of his time. ${ }^{28}$ "The fiery old man had been bowled over by Augustine's generous, self-effacing appeal . ." ${ }^{29}$ writes Kelly.

Precisely how did Augustine smooth the ruffled relationship? The transformation is marked. In a letter to his friend Praesidius, Augustine noted the tension: ${ }^{30}$ "When you read these (early letters of Jerome and Augustine) you will appreciate the moderation I have felt it necessary to observe; you also will be aware of the agitated state of his mind and will see that I have reason to fear it." Yet Jerome ultimately would praise Augustine as "a holy and eloquent bishop" ${ }^{\prime 31}$ whose recent works on infant baptism obviated the need for additional work by Jerome.

Augustine's strategy is a simple one. Without hedging on his

${ }^{28}$ J. M. Sailer, Briefe aus allen Jahrhunderten (1800), I, p. 134.

${ }^{29}$ Kelly, p. 270.

${ }^{30}$ PL 33 (Ep. LXXIV.1.)

${ }^{31}$ Dial. Adv. Pelag. III. 804. Near the end of Jerome's life, he and Augustine joined forces to battle the Pelagians. Jerome responded to news that the Council of Diospolis (415) had acquitted Pelagius by writing Dialogi contra Pelagianos, his last polemical work. Between 412 and his death in 430, Augustine produced sixteen works attacking Pelagianism. 
claim about the dissimulatio of Peter, Augustine replaces Jerome's metaphors prophesying destruction with metaphors foretelling cure. At the same time, Augustine severs the link between the request for a palinode and Jerome's traumatic battle with Rufinus by empathizing with Jerome over the pain of that breach. All of this is prefaced with an apology for the ill chosen and offensive phrase and careful reiteration of its intended meaning.

Augustine begins in his letter of 404 A.D. by transforming Jerome/Entellus the boxer to Jerome/Entellus the physician. The reconstruction of the metaphor grants Jerome the superior role his original metaphor assumed while soliciting the restraint the metaphors imply and transforming their projected outcomes from conquering to healing. Augustine asks, "Why, then, shall I fear your words, hard, perhaps, like the gloves of Entellus, but certainly determined to do me good? The blows of Entellus were intended not to heal, but to hurt, and therefore his opponent was conquered not cured." 32

In Augustine's reconstruction, the blows of Jerome are not retributive but medicinal: "But if I receive your correction tranquilly as a necessary medicine, I shall not be pained by it."

If Jerome inflicts pain, Augustine will endure it confident of its curative power. "If however, through weakness, either common to human nature or unique to me, I cannot but feel some pain from rebuke, even when I deservedly am reproached, it is far better to have a tumor in one's head cured, even though the knife cause pain, rather than avoid the pain by letting the disease grow." That line of argument forces Jerome into a Christian frame of reference that he and Augustine share. Both believe in the reformative power of pain as a means of spiritual advancement. The notion that the Christian must die unto himself in order to live everlastingly is as commonplace in their writings as is the assumption that a person has a right, indeed an obligation, to inflict pain on another if that will facilitate spiritual growth. So, for example, Augustine notes in his Confessions that God had broken his bones in order to heal him. ${ }^{33}$ Similarly, Jerome dreamt that he was flogged before the heavenly throne for embracing Ciceronianism. ${ }^{34}$

${ }^{12}$ PL 33 (Ep LXXIII, II. 4 ff)

${ }^{33} 2.2 ; 7.20$ in CSEL, 33.

${ }^{34}$ Ep. 27. 39; CSEL, 54. See also S. F. Bonner, Education in Ancient Rome (Berkeley: Univ. of Calif. Press, 1977), pp. 143-5; Karl F. Morrison The Mimetic Tradition of 
Augustine's transformed metaphor argues implicitly that Jerome's blows are explanable and justified insofar as they cure Augustine. At the same time, the reconstructed metaphor both argues that Jerome must respond to Augustine's doctrinal contention about the mendacium officiosum of St. Peter and corners Jerome: if he accepts its confines, he can either behave as a hurtful brute or a healing physician: a no-choice choice.

As both Augustine and Jerome are aware, Jerome's recent savaging of Rufinus is the threat Jerome-Entellus is brandishing and the threat Augustine is dodging. In the same letter, Augustine acknowledges that "nothing made me quake more than your estrangement from Rufinus, when I read in your letter some of the indications of your being displeased with me."

Yet one metaphor of threat remains to be defused before Augustine can fracture Jerome's tie between Rufinus and Augustine. In transforming the metaphor of the ox, Augustine allays the fear that he is about to charge Jerome with heresy. He does this by building a metaphor affirming Jerome's strength and his value to the Church. "Therefore, since you are, to cite your own analogy, an ox worn down-perhaps worn down in bodily strength by reason of age, but unimpaired in mind and working sitll diligently and profitably on the Lord's threshing floor; here I am, and insofar as I have spoken ill, tread firmly on me; the weight of your revered age ought not trouble me, if by it the chaff of my fault is separated under foot from me."

Again, a destructive metaphor has turned constructive. Again Jerome's superiority is acknowledged, his threats transformed to blessings and the obligation to respond to Augustine's doctrinal query underscored.

Having recast the relationship implied by Jerome's metaphors, Augustine must exorcise the ghost of Rufinus from the exchange. In the remainder of the letter Augustine will argue implicitly, that, unlike Augustine, Rufinus forced Jerome to become the hurtful Entellus. At the same time Augustine will sorrow at the animus between Jerome and his former friend.

A reader might ask why when to this point in the exchange Jerome has not even uttered Rufinus' name, Augustine responds

Reform in the West (Princeton, NJ: Princeton Univ. press, 1982), pp. 84-88. The notion that chastisement is good for the soul has secular roots as well. Cf. Plato's Gorgias. 505; 507; 525; 35. PL, 33 (ep. LXXIII. III.6) 
to Jerome's letter of the threatening metaphors in a letter preoccupied with Rufinus. The answer is an obvious one. Augustine senses that Jerome is not responding to him on his own terms but to him as a potential Rufinus: a wolf in friend's clothing. In this realization lies Augustine's rhetorical genius.

Augustine mutes Jerome's fears and at the same time enwraps Jerome in a metaphor that argues that he is armed not as an aggressor but as a defender and not as a defender against any single man but against the devil. Augustine premises his closing argument on the contention that he would rather that they not debate if the outcome will be wounded friendship. In short, he assures Jerome that he will not do to him what Rufinus has done: "If it is not possible for either of us to identify what he judges to demand correction in the other's writings, without being suspected of envy and regarded as wounding friendship, let us, concerned for our spiritual life and well-being, abandon such discussion."

The last section of the letter is devoted to justifying Jerome's response to Rufinus while regretting that the response itself was necessary. "While any person of discernment may see in your own example how, comforted by a good conscience you bear what otherwise would be unbearable-the incredible hatred of one who was formerly your most intimate and beloved friend, and how even what he states against you, even what may be to your disadvantage, believed by some, you turn to good account as the armor of righteousness on the left hand, which is not less useful than armor on the right hand in our warfare with the devil." According to Augustine, Jerome was merely defending against the bitter charges of Rufinus. Yet the bitterness of the charges and the bitterness of the response are regrettable. "But indeed I rather would see him less bitter in his accusations than see you more fully armed by them."

In summary, Augustine's call for a Stesichoran recantation unintentionally employed a capsulizing phrase that for Jerome symbolized betrayal by a person he had regarded as a brother. Jerome's insistent misreading of the call for a palinode reveals that the explanation for his menacing rhetoric resided not in the immediate situation but in Jerome's past. Jerome's choice from among the available means of persuasion was not then the inevitable by-product of a bilious nature but was rather circumscribed by his traumatic exchange with Rufinus. Augustine's ability to resolve the conflict hinged on his awareness that the phrase "Stesichoran palinode" 
had summoned in Jerome raw, bleeding memories of his fratricidal battle with Rufinus.

By making it impossible for Jerome to cast him as Rufinus, Augustine clarified Jerome's blurred perception of the ill-chosen request for a palinode. The transformed metaphors create a frame of reference in which Jerome cannot reduce Augustine either to a beaten, toothless challenger or to Rufinus. Unlike Rufinus, Augustine is willing to be separated from his error by the ox-Jerome or pained in the process of removal of a tumor by the physicianJerome. Jerome's fear that Augustine too would betray him is allayed by Augustine's extended sympathetic treatment of the breach with Rufinus and by metaphoric transformation of roles which precludes Jerome's misinterpretation of the call for palinode. In the final exchange of letters, Augustine completes the transformation by explicitly casting Jerome as his teacher.

If the exchange between Jerome and Augustine had propelled the Catholic Church into schism, unraveling its cause would have undisputable significance. Although it instead ended in reconciliation, the exchange remains instructive. Not only does it reveal the rhetorical dispositions and talents of two noted rhetorical practitioners, but it also illustrates the character of metaphor and of metaphoric transformation. Had Jerome issued non-metaphoric threats to bloody Augustine, the Bishop's ability to redefine the encounter would have been importantly circumscribed. The distance the metaphors invite between author and word provides room for reconciliation. The ambiguity inherent in the metaphors serves the same end.

The interchange reminds us, as well, that the immediate situation is not necessarily the decisive force shaping rhetoric. Elsewhere ${ }^{35} \mathrm{I}$ argued that rhetoric can be formed by factors in the distant past. Specifically, the contemporary papal encyclical bears the imprint of extinct ancestral genres. The perseverative power of the "Stesichoran palinode" provides an additional instance of the haunting presence of past discourse. Here an ill-chosen but ostensibly innocent phrase of Augustine's prompted Jerome to make threats he would not otherwise have made. Critics unmindful of the tenacious grip past utterances can place on discourse will find exchanges such as that between Jerome and Augustine unfathomable.

${ }^{35}$ Kathleen M. Jamieson, "Antecedent Genre as Rhetorical Constraint," Quarterly Journal of Speech, 61 (Dec. 1975), pp. 406-415. 
